\title{
Thallium isotope constraints on subduction recycling in the Southern Andes Arc
}

\author{
MARIE KATRINE TRAUN ${ }^{1}$, EMILY CATHERINE POPE ${ }^{2}$, \\ QUINTEN VAN DER MEER ${ }^{3}$, SUNE GRØNLUND \\ NIELSEN $^{4}$, NINA SØAGER ${ }^{1}$ AND TOD EARLE WAIGHT ${ }^{1}$ \\ ${ }^{1}$ University of Copenhagen \\ ${ }^{2}$ Colorado College \\ ${ }^{3}$ University of Iceland \\ ${ }^{4}$ Woods Hole Oceanographic Institution
}

Presenting Author: marie.traun@gmail.com

The Andean subduction zone supplies a major fraction of the global deep cycle of sediments to the mantle. However, a discrepancy exists between the arc lavas and trench sediments in the Southern Andes Arc. Unlike many other subduction zones, addition of shelf and trench proximal sediment to the mantle wedge cannot fully account for the radiogenic isotope variation observed in the Southern Andes Arc lavas. Thus, geochemists have invoked subduction erosion of continental crust or contamination of crustal components to explain the observed variations in the volcanic compositions. In this presentation, we give new insights on distinguishing these components using multiple radiogenic and stable isotope systems, including thallium isotopes, from three previously studied volcanoes in the Southern Andes Arc; Maipo, Laguna del Maule and Infernillo. Thallium isotope compositions have proven useful to characterize sedimentary components in some volcanic island arcs, because the thallium isotope compositions of oceanic crust, pelagic sediments and continental crust are distinct. Here for the first time, we apply thallium isotopes to a continental arc setting with the aim of distinguishing previously hypothesized crustal recycling processes in the Southern Andes Arc. Preliminary thallium isotope results from the Southern Andes Arc lavas potentially indicate the presence of recycled pelagic sediment in two of the studied volcanoes; Laguna del Maule and Infernillo, as these generally display heavier thallium isotope compositions. Radiogenic isotopes suggest this pelagic sediment is likely akin to marine sediments off shore on the Nazca Plate. The third and northernmost volcano, Maipo, displays thallium isotope compositions similar to the average continental crust and upper mantle. The results for Maipo are thus consistent with the previous interpretation of continental crust influences. We hypothesize that the preservation of a pelagic sediment signature and the general variability of the arc lavas relate to a northward change in the geometry of the subduction zone from an accretionary to an erosive style margin. 